\title{
Barbara Wyrzykowska
}

Szkoła Główna Gospodarstwa Wiejskiego w Warszawie e-mail: barbara_wyrzykowska@sggw.pl

\section{NOWE TENDENCJE W BADANIU KOMPETENCJI MENDŻERSKICH - STUDIA LITERATUROWE}

\section{NEW TRENDS IN THE STUDY OF MANAGERIAL COMPETENCES - LITERATURE STUDIES}

DOI: $10.15611 /$ pn.2018.512.25

Streszczenie: Ze względu na rosnące znaczenie kompetencji dla funkcjonowania współczesnych organizacji istnieje zapotrzebowanie na nowe narzędzia umożliwiające menedżerom efektywniejsze zarządzanie tym rodzajem zasobów. W opracowaniu przedstawiono zarys koncepcji agregatowej oceny kompetencji menedżerskich. Kompetencje podlegają ocenie przy zastosowaniu większej liczby kryteriów oceny. Taki sposób uzasadnia się tym, że ocena wielokryterialna jest pełniejsza i daje bardziej kompletny obraz stanu faktycznego posiadanych kompetencji . Wyniki agregatowej oceny kompetencji kadry menedżerskiej w skali jednostkowej powinny być wykorzystane do ustalenia wysokości wynagrodzeń zasadniczych dla poszczególnych menedżerów. Natomiast w skali całego przedsiębiorstwa powinny stanowić informację, która zostanie wykorzystana w kształtowaniu systemu premiowania kadry menedżerskiej, pobudzającego jej efektywność i zaangażowanie.

Słowa kluczowe: kompetencje menedżerskie, metody oceny kompetencji menedżerskich, agregatowa ocena kompetencji menedżerskich.

Summary: Due to the growing importance of competences for the functioning of modern organizations, there is a need for new tools that enable managers to manage this type of resources more effectively. The study outlines the concept of aggregate assessment of managerial competences. Competences are evaluated using a larger number of assessment criteria. Such a method is justified by the fact that the multi-criteria assessment is more complete and gives a more complete picture of the actual state of the competencies held. The results of the aggregate assessment of managerial competencies on a unit scale should be used to determine the amount of basic salaries for individual managers. On the other hand, in the scale of the entire enterprise, there should be information that will be used in shaping the bonus system for the managerial staff, in order to stimulate its effectiveness and commitment.

Keywords: managerial competences, methods of managerial competence assessment, aggregate assessment of managerial competences. 


\section{Wstęp}

Ze względu na rosnące znaczenie kompetencji dla funkcjonowania współczesnych organizacji istnieje zapotrzebowanie na nowe narzędzia umożliwiające menedżerom efektywniejsze zarządzanie tym rodzajem zasobów. Wskazanie optymalnej metody oceny kompetencji jest trudne ze względu na kontekst realizacji procesu oceny oraz interdyscyplinarny charakter kompetencji. Wybierając metodę oceny kompetencji menedżerskich, należy wziąć pod uwagę różne sposoby oceny kompetencji menedżerskich dostosowane każdorazowo do: celu oceny, rodzaju badanych kompetencji, kondycji ekonomiczno-finansowej danej organizacji, wielkości przedsiębiorstwa, kompetencji podmiotów odpowiedzialnych za politykę personalną oraz podmiotów realizujących proces oceny [Kupczyk, Stor 2017, s. 40-50].

Celem artykułu jest dokonanie przeglądu metod diagnozowania kompetencji kadry menedżerskiej oraz przedstawienie koncepcji agregatowej oceny kompetencji menedżerskich. W koncepcji tej kompetencje podlegają ocenie przy zastosowaniu większej liczby kryteriów oceny. Taki sposób uzasadnia się tym, że ocena wielokryterialna jest pełniejsza i daje bardziej kompletny obraz stanu faktycznego posiadanych kompetencji. Podstawową metodę badawczą stanowiły studia literaturowe, wzbogacone wnioskami i obserwacjami zgromadzonymi przez autorkę.

\section{Specyfika kompetencji menedżerskich}

Nie ma pełnej zgody co do tego, jakie konkretnie kompetencje powinny charakteryzować efektywnego menedżera. Ogromna rozmaitość stanowisk kierowników - i podmiotów, którymi kierują - sprawia, że opisywanie ich kompetencji w sposób uniwersalny, ujednolicony byłoby niezasadne. Trzeba uwzględnić swoistość wymagań różnych szczebli zarządzania. To bowiem, co jest najważniejsze w pracy prezesa zarządu czy dyrektora naczelnego, najczęściej nie ma takiego znaczenia w wypadku kierowników pierwszej linii, i odwrotnie. Inna jest struktura kompetencji osób zarządzających na przykład produkcją, a inna ludzi zarządzających projektami czy finansami [Oleksyn 2018, s. 168].

Wszyscy menedżerowie, niezależnie od poziomu kierowania, mają jednak kilka kompetencji wspólnych, należą do nich kompetencje [Wyrzykowska 2016, s. 1074-1082]:

- osobiste - związane z indywidualnym sposobem realizacji zadań. Poziom tych kompetencji wpływa na ogólną jakość wykonywanych zadań - decyduje o szybkości, jakości i zaangażowaniu w podejmowane działania;

- społeczne - wpływają na sposób budowania i jakość relacji z innymi oraz sposób wykonywania zadań związanych z takimi kontaktami. Poziom tych kompetencji decyduje o skuteczności współpracy, porozumiewania się i wywierania wpływu na innych; 
- stanowiskowe (menedżerskie i przywódcze) - są związane z zarządzaniem pracownikami i organizacjami. Dotyczą zarówno miękkich obszarów kierowania, organizacji pracy, jak i strategicznych aspektów zarządzania. Poziom tych kompetencji decyduje o skuteczności zarządzania.

Istnieje przesłanka, że struktura kompetencji osobistych, społecznych i menedżerskich odzwierciedla wartości wyznawane przez menedżerów (przywódców) organizacji i związane z nimi dominujące techniki zarządzania i style przewodzenia [Czubasiewicz, Nogalski 2010, s. 147]. Znaczenie każdej z tych grup jest jednak inne w zależności od szczebla zarządzania i rodzaju prowadzonej działalności.

Kompetencje możemy rozpatrywać w ujęciu statycznym oraz dynamicznym. Kompetencje w znaczeniu statycznym to zdolność pracownika do wykonywania na stanowisku pracy tego, co potrzebne. Można je opisać za pomocą właściwych dla kompetencji menedżerskich atrybutów, takich jak: osobowość, wiedza, umiejętności, doświadczenie, odpowiedzialność. Z kolei kompetencje w znaczeniu dynamicznym zostały wzbogacone o takie atrybuty, jak postawy i zachowania [Jabłoński 2011, s. 105-109]. Takie rozumienie kompetencji determinuje potrzebę oceny kompetencji w wymiarze statycznym ${ }^{1}$ i dynamicznym ${ }^{2} \mathrm{z}$ równoczesnym uwzględnieniem zależności przyczynowo-skutkowych między tymi wymiarami, po to by w rezultacie ustalić poziom oceny agregatowej.

\section{Metody oceny kompetencji menedżerskich}

W dalszej części opracowania przedstawiono klasyfikację metod oceny kompetencji menedżerskich. Prezentowana klasyfikacja zakłada podział metod, które powstały na gruncie takich dyscyplin naukowych, jak zarządzanie, psychologia czy etyka. W ramach tego podziału wyszczególniono także standardy kwalifikacji zawodowych mające charakter rozwiązań formalnoprawnych stosowanych w różnych państwach europejskich (tabela 1).

Ponadto metody oceny kompetencji kadry menedżerskiej zostały podzielone na standaryzowane i niestandaryzowane. Do metod standaryzowanych należą testy psychologiczne oraz standardy kwalifikacyjne. Natomiast metody opracowane na gruncie nauk o zarządzaniu i narzędzia oceny zachowań zgodnych z etyką biznesu to metody niestandaryzowane.

Metody powstałe na gruncie nauk o zarządzaniu wskazują kompetencje menedżerów, które są preferowane w przedsiębiorstwie ze względu na realizowaną strategię. Podstawę oceny kompetencji stanowi stopień realizacji celów strategicznych, za które odpowiada menedżer. Cele strategiczne wyznaczają kompetencje, których oczekuje się od menedżerów, oraz kryteria i zasady ich oceny. Służą one do diagno-

${ }^{1}$ Celem statycznej oceny kompetencji menedżerskich jest wycena punktowa profili kompetencyjnych poszczególnych stanowisk menedżerskich.

${ }^{2}$ Celem dynamicznej oceny kompetencji menedżerskich jest ustalenie luki kompetencyjnej. 
Tabela 1. Metody oceny kompetencji menedżerskich

\begin{tabular}{|c|c|c|c|c|c|}
\hline \multicolumn{3}{|c|}{ Metody w naukach o zarządzaniu } & \multirow{3}{*}{$\begin{array}{c}\text { Metody } \\
\text { psychologiczne }\end{array}$} & \multirow{3}{*}{$\begin{array}{c}\text { Standardy } \\
\text { kwalifikacji } \\
\text { zawodowych }\end{array}$} & \multirow{3}{*}{$\begin{array}{c}\text { Narzędzia oceny } \\
\text { zachowań zgodnych } \\
\text { z etyką biznesu }\end{array}$} \\
\hline \multirow{2}{*}{$\begin{array}{l}\text { Metody } \\
\text { relatywne }\end{array}$} & \multicolumn{2}{|c|}{ Metody absolutne } & & & \\
\hline & Metody par excellence & Metody pomocnicze & & & \\
\hline $\begin{array}{l}\text { - } \text { ranking } \\
\text { - } \text { porównanie } \\
\text { parami }\end{array}$ & $\begin{array}{l}\text { - } \text { zwykły zapis } \\
\text { - } \text { technika wydarzeń } \\
\text { - } \text { techntycznych } \\
\text { - } \text { metoda porównania ze } \\
\text { standardami } \\
\text { - ośrodki oceny } \\
\text { - ośrodki rozwoju } \\
\text { - portfolio personalne } \\
\text { - testy wiadomości } \\
\text { - } \text { arkusze ocen } \\
\text { - listy kompetencyjne } \\
\text { - modele kompetencyjne } \\
\text { - profile kompetencyjne } \\
\text { - metody wartościowania } \\
\text { - kompetencji } \\
\text { - panele eksperckie }\end{array}$ & 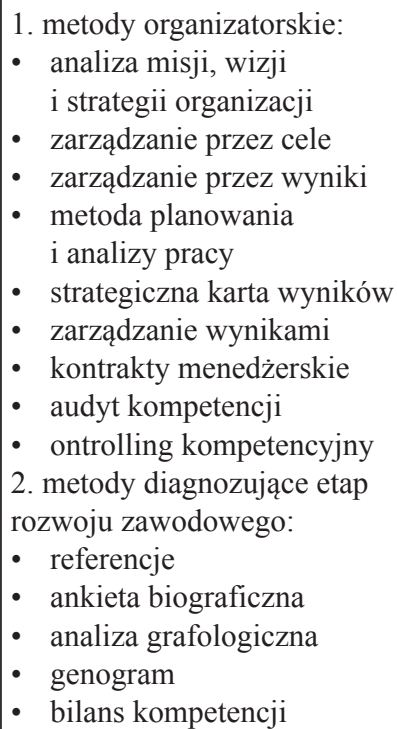 & $\begin{array}{ll}\text { - } & \text { testy inteligencji } \\
\text { - } & \text { testy osobowości } \\
\text { - } & \text { testy postaw } \\
\text { - } & \text { testy umiejętności } \\
\text { - } & \text { esty uzdolnień }\end{array}$ & $\begin{array}{ll}\text { - } & \text { brytyjskie } \\
\text { - } & \text { niemieckie } \\
\text { - } & \text { francuskie } \\
\text { - } & \text { holenderskie } \\
\text { - } & \text { słoweńskie } \\
\text { - } & \text { łotewskie } \\
\text { - } & \text { polskie }\end{array}$ & $\begin{array}{l}\text { - } \text { procedury etyczne } \\
\text { - } \text { kontrola etyczna } \\
\text { - } \text { kodeksy } \\
\text { - postępowania } \\
\text { - } \text { programy etyczne } \\
\text { - } \text { konsolenia etyczne } \\
\text { konsultanci ds. etyki }\end{array}$ \\
\hline
\end{tabular}

Źródło: [Tyrańska 2015, s. 68]. 
zowania postaw i zachowań, które są przejawem posiadania lub braku posiadania przez menedżerów kompetencji niezbędnych do skutecznego wykonywania pracy. Metody te podzielono na dwie kategorie: relatywne i absolutne [Czubasiewicz 2005, s. 96].

Relatywna ocena kompetencji menedżerskich może być przeprowadzona na podstawie porównywania menedżerów. Wśród metod relatywnych najczęściej stosowane są takie metody, jak ranking i porównanie parami. Metoda absolutna polega na porównaniu kompetencji posiadanych przez menedżerów z opracowanymi standardami ich oceny. W ramach metod absolutnych dodatkowo wyróżniono metody par excellence, czyli metody wypracowane bezpośrednio na potrzeby diagnozy kompetencji, oraz metody pomocnicze, do których zaliczono metody organizatorskie i metody diagnozujące etap rozwoju zawodowego menedżera [Tyrańska 20015, s. 95].

Metody par excellence mają znacznie większą trafność diagnostyczną niż relatywne metody oceny. Niektóre z tych metod służą wyłącznie do oceny jednego składnika kompetencji - wiedzy (np. testy wiedzy merytorycznej). Natomiast inne mają bardziej kompleksowy charakter i umożliwiają ocenę różnych składników kompetencji menedżerskich (np. ośrodki oceny i ośrodki rozwoju). Wśród absolutnych metod oceny kompetencji kadry menedżerskiej wyróżniono: zwykły zapis, technikę wydarzeń krytycznych, technikę list kontrolnych, metodę porównania ze standardami, ośrodek oceny (assessment center), ośrodek rozwoju (development center), portfolio personalne, testy wiadomości, arkusze ocen, listy, modele i profile kompetencyjne, wartościowanie kompetencji i panele eksperckie. Wymienione narzędzia wzajemnie się uzupełniają w zakresie identyfikacji i diagnozy wymogów kompetencyjnych dla stanowisk menedżerskich [Nieżurawska 2010].

Metody opracowane na gruncie nauk o zarządzaniu ewoluują w kierunku metod bardziej złożonych, np. audytu kompetencyjnego czy controllingu kompetencyjnego. Wymagają one jednak użycia wielu metod pomocniczych.

W psychologii ocena kompetencji kadry menedżerskiej jest prowadzona w ramach postępowania nazwanego diagnozą psychologiczną ${ }^{3}$. Witkowski wskazuje, że diagnoza psychologiczna ma trzy cele: różnicowanie osobowościowo-kliniczne, opracowanie ekspertyz psychodydaktycznych oraz ocenę przydatności zawodowej [Witkowski 1995, s. 47]. W tym szczególnym przypadku, jakim jest ustalenie przydatności danej osoby do pracy i do wykonywanego zawodu, psychologowie koncentrują się na ocenie kompetencji społecznych, inteligencji emocjonalnej, cech osobowości, a także badają kontekst działania jednostki.

Ocena potencjału intelektualno-osobowościowego menedżera jest trudna w realizacji, ponieważ wymaga zastosowania specyficznych metod pozwalających ustalić związek między cechami osobowości, inteligencją, nastawieniem do wykonywania

\footnotetext{
${ }^{3}$ Diagnoza psychologiczna to rozpoznanie jakiegoś stanu rzeczy i tendencji rozwojowych na podstawie jego objawów, opierając się na znajomości ogólnych prawidłowości.
} 
różnych czynności a konkretnymi zachowaniami. Do diagnozowania wskazanych związków psychologowie wykorzystują testy. Występują one w postaci zbioru zadań lub pytań, które w standardowych warunkach mają wskazywać określone rodzaje zachowań i dostarczyć wyników o pożądanych właściwościach psychometrycznych, tj. posiadających wysoką rzetelność i trafność. Klasyfikację testów psychologicznych można przeprowadzić, stosując kryterium przedmiotu badań, według którego wyróżnia się testy: inteligencji, osobowości, postaw, umiejętności i uzdolnień [Wieczorek-Szymańska 2012, s. 106-109].

Niewątpliwą zaletą metod psychologicznych jest ich standaryzacja, która zapewnia obiektywność pomiaru kompetencji oraz umożliwia porównywanie wyników. Do wad tych metod zaliczyć należy to, że użycie testu następuje wyłącznie za zgodą kandydata, oraz to, że testy analizują zachowanie osoby, ale nie uwzględniają sytuacji jako czynnika istotnego dla tego zachowania. Uzyskane za ich pomocą wyniki mogą być pomocne w kształtowaniu kariery zawodowej, w której menedżer ma szansę się sprawdzić, a także w zrozumieniu przyczyn braku satysfakcji z pracy lub trudności w niej [Whiddett, Hollyforde 2003, s. 94].

Standardy kwalifikacyjne, stanowiące swoisty wzorzec kwalifikacyjny, mogą być przydatne do tworzenia opisów stanowisk pracy, profili kompetencyjnych i wartościowania kompetencji zgodnie $\mathrm{z}$ wymogami obowiązującymi na rynku pracy w danym kraju. W poszczególnych państwach obowiązują krajowe klasyfikacje zawodów, które są zgodne z klasyfikacjami międzynarodowymi. Przestrzeganie standardów gwarantuje odpowiednią jakość wykonywania zadań na stanowiskach pracy [Kwiatkowski 2004, s. 9].

Każdy kraj ma inną filozofię tworzenia standardów zawodowych. W Polsce na potrzeby rynku pracy obowiązuje opracowana w grudniu 2002 r. wspólna dla gospodarki i edukacji klasyfikacja zawodów ${ }^{4}$ i specjalności. Klasyfikacja jest stosowana w szczególności w zakresie: 1) pośrednictwa pracy i poradnictwa zawodowego; 2) szkolenia osób poszukujących pracy oraz dokształcania pracowników; 3) gromadzenia danych do określenia polityki zatrudnienia, kształcenia i szkolenia zawodowego; 4) prowadzenia badań, analiz, prognoz i innych opracowań dotyczących rynku pracy [Rozporządzenie Ministra Gospodarki 2004].

Narzędzia oceny zachowań zgodnych z etyką biznesu odwołują się do wzorca etycznego. Wśród wielu wymogów, które wzorcowy menedżer powinien spełnić, wymienia się posiadanie kompetencji, co w praktyce sprowadza się do należytego przygotowania zawodowego i odpowiedniej praktyki, umiejętności wykorzystania

\footnotetext{
${ }^{4}$ Zgodnie z polską klasyfikacją zawodów kierownicy należą do grupy pierwszej, obok parlamentarzystów i wyższych urzędników. Dla grupy pierwszej jako kryterium grupowania zawodów i specjalności zastosowano „funkcję tworzenia polityki i prawa oraz zarządzania”. Podstawowymi zadaniami zawodów zaliczanych do grupy pierwszej są planowanie, określanie i realizowanie podstawowych celów i kierunków polityki państwa, formułowanie przepisów prawnych oraz kierowanie działalnością jednostek administracji publicznej, a także sprawowanie funkcji zarządzania w przedsiębiorstwach lub ich wewnętrznych jednostkach organizacyjnych.
} 
wiedzy w dziedzinach związanych z działalnością, którą kieruje. Wymóg kompetencji dopełniają umiejętności: organizacyjne, współdziałania z zespołem, komunikowania się i podejmowania decyzji. Etyczna ocena kompetencji menedżerskich wartościuje zachowania menedżera, ustala, czy przebiegały one zgodnie z uniwersalnymi dyrektywami etycznymi oraz czy menedżer wykorzystał odpowiednio posiadane kompetencje, zarządzając danym przedsięwzięciem [Zbiegeń-Maciąg 2006, s. 214].

Posługiwanie się metodami niestandaryzowanymi ze względu na ich dokładniejsze dopasowanie do potrzeb konkretnej organizacji daje lepsze rezultaty w ocenie kompetencji kadry menedżerskiej niż zastosowanie metod standaryzowanych [Miś 2007, s. 141].

\section{Koncepcja agregatowej oceny kompetencji menedżerskich}

Ocena agregatowa to syntetyczne oszacowanie wartości kompetencji kadry menedżerskiej. Polega ona na łączeniu w jedną całość pojedynczych kryteriów oceny. Kompetencje podlegają ocenie przy zastosowaniu większej liczby kryteriów (co najmniej dwóch). Taki sposób oceny uzasadnia się tym, że ocena wielokryterialna jest pełniejsza i daje bardziej kompletny obraz stanu faktycznego.

Formułę agregatowej oceny wzorcowego poziomu kompetencji na poszczególnych poziomach zarządzania można przedstawić w postaci indeksu punktacji ważonej:

$$
K W_{i}=\sum_{j=1}^{n} w_{i} \cdot k_{i j},
$$

gdzie: $K W_{i}$ - wzorcowy poziom kompetencji dla $i$-tego stanowiska menedżerskiego na danym szczeblu zarządzania, przy czym $i=1, \ldots, m, w_{i}$ - waga $i$-tej grupy kompetencji ustalona dla danego poziomu zarzadzania, $k_{i j}$ - ocena wzorcowa dla $i$-tej grupy kompetencji menedżerskich na $j$-tym szczeblu zarządzania, $\operatorname{przy} \operatorname{czym} j=1, \ldots n$.

Ocena wzorcowa $\left(k_{i j}\right)$ dla $i$-tej grupy kompetencji menedżerskich na $j$-tym szczeblu zarządzania jest wyznaczona na zasadzie średniej arytmetycznej not punktowych ustalonych dla poszczególnych kryteriów oceny według przyjętego w metodzie wartościowania kompetencji klucza analitycznego. Wynik agregatowanej oceny kompetencji kadry menedżerskiej ma bardzo ważne znaczenie w procesie kategoryzacji poziomu kompetencji menedżerskich.

Po ustaleniu wyceny punktowej profili kompetencyjnych (ocenie statycznej ${ }^{5}$ ) oraz przeprowadzeniu indywidualnych ocen kompetencji menedżerów zatrudnio-

\footnotetext{
${ }^{5}$ Pomiar kompetencji w proponowanej metodyce jest przeprowadzany z wykorzystaniem analityczno- punktowej metody wartościowania kompetencji. Noty punktowe dla poszczególnych kryteriów oceny kompetencji stanowią pochodną złożonej 5-stopniowej skali.
} 
nych na poszczególnych stanowiskach pracy (ocenie dynamicznej`) można przystąpić do kategoryzacjī poziomu kompetencji badanych menedżerów.

Ostateczną kategorię zaszeregowania dla danego menedżera można ustalić, szacując stopień kompetencyjności ${ }^{8}$ ocenianych menedżerów. Formuła wskaźnika stopnia kompetencyjności jest następująca:

$$
P K_{i}=\frac{K M_{i}}{K W_{i}} \quad \mathrm{z} \text { założenia } \quad K M_{i} \geq K W_{i}, K W_{i} \neq 0,
$$

gdzie: $P K_{i}$ - stopień kompetencyjności $i$-tego menedżera, $K W_{i}$ - wzorcowy poziom kompetencji dla $i$-tego stanowiska menedżerskiego na danym szczeblu zarządzania, $K M_{i}$ - rzeczywisty poziom kompetencji $i$-tego menedżera.

Jeżeli $P K_{i}$ jest równy lub większy od jedności, oznacza to, że menedżer ma wszystkie wymagane kompetencje na poziomie zgodnym z wzorcowym (określonym dla danego stanowiska) lub przewyższającym poziom wzorcowy. Z kolei im mniejsze jest $P K_{i}$, tym niższy jest stopień posiadania przez menedżerów wymaganych kompetencji. Przeprowadzona kategoryzacja pozwala na zakwalifikowanie menedżera do jednej z wyróżnionych kategorii: eksperta, specjalisty, uczącego się lub balastu. Przyjętą kategoryzację $P K_{i}$ wskaźnika przedstawiono w tab. 2 .

Tabela 2. Kategoryzacja rzeczywistego stopnia kompetencyjności kadry menedżerskiej

\begin{tabular}{|c|l|l|}
\hline $\begin{array}{c}\text { Kategoria } \\
\text { menedżerów }\end{array}$ & $\begin{array}{c}\text { Kategoryzacja } \\
\text { wskaźnika }\end{array}$ & \multicolumn{1}{c|}{ Charakterystyka } \\
\hline 1 & 2 & \multicolumn{1}{c|}{3} \\
\hline Ekspert & $\geq 90$ & $\begin{array}{l}\text { Doskonaty stopień kompetencyjności } \\
\text { Poziom posiadanych kompetencji wskazuje na pełny lub wyższy } \\
\text { poziom stanu rzeczywistego w porównaniu ze stanem wzorcowym. } \\
\text { Posiadane kompetencje umożliwiają twórcze ich wykorzystanie } \\
\text { i rozwijanie }\end{array}$ \\
\hline Specjalista & $0,60-0,89$ & $\begin{array}{l}\text { Wysoki stopień kompetencyjności } \\
\text { Poziom posiadanych kompetencji wskazuje na małą rozbieżność } \\
\text { między stanem wzorcowym a rzeczywistym. Posiadane } \\
\text { kompetencje pozwalają na dobrą realizację zadań z danego zakresu } \\
\text { oraz przekazywanie innym własnych doświadczeń }\end{array}$ \\
\hline
\end{tabular}

${ }^{6}$ Uzupełnieniem statycznej oceny kompetencji menedżerskich jest ocena dynamiczna, identyfikująca rzeczywisty poziom kompetencji posiadanych przez menedżerów. Wykorzystuje ona model $360^{\circ}$ oraz analizy dokumentacji organizacyjnej i ekonomicznej.

${ }^{7}$ Kategoryzacja umożliwia podjęcie decyzji w zakresie ostatecznej taryfikacji menedżerów i wyznaczanie adekwatnego do reprezentowanych kompetencji poziomu płacy zasadniczej.

${ }^{8}$ Stopień kompetencyjności jest miarą zgodności między stanem faktycznym (rzeczywistym) a wartością modelową (wzorcowym poziomem wymagań kompetencyjnych określonych dla danego stanowiska menedżerskiego). 
Tabela 2, cd.

\begin{tabular}{|l|l|l|}
\hline \multicolumn{1}{|c|}{1} & \multicolumn{1}{|c|}{2} & \multicolumn{1}{c|}{3} \\
\hline Uczący się & $0,30-0,59$ & $\begin{array}{l}\text { Zadowalający stopień kompetencyjności } \\
\text { Poziom posiadanych kompetencji wskazuje na znaczną } \\
\text { rozbieżność między stanem wzorcowym a rzeczywistym. } \\
\text { Posiadane kompetencje pozwalają na samodzielne realizowanie } \\
\text { zadań zawodowych, ale wymagana jest okresowa kontrola osób } \\
\text { bardziej doświadczonych }\end{array}$ \\
\hline Balast & $0,00-0,29$ & $\begin{array}{l}\text { Niesatysfakcjonujący stopień kompetencyjności } \\
\text { Poziom posiadanych kompetencji wskazuje na całkowitą } \\
\text { rozbieżność między stanem wzorcowym a rzeczywistym. Sytuacja } \\
\text { ta wymaga stałego nadzoru i aktywnego wsparcia ze strony osób } \\
\text { bardziej doświadczonych }\end{array}$ \\
\hline
\end{tabular}

Źródło: opracowanie własne na podstawie [Tyrańska 2015, s. 124].

Ostateczne wyniki oceny kompetencji kadry menedżerskiej w skali jednostkowej powinny być wykorzystane do ustalenia wysokości wynagrodzeń zasadniczych dla poszczególnych menedżerów. Natomiast w skali całego przedsiębiorstwa powinny stanowić informację, która zostanie wykorzystana w kształtowaniu systemu premiowania kadry menedżerskiej, pobudzającego jej efektywność i zaangażowanie.

\section{Konkluzje}

Decydując o wyborze metod, należy uwzględnić różne sposoby oceny kompetencji menedżerskich dostosowane każdorazowo do specyfiki przedsiębiorstwa, jego strategii, a przede wszystkim do stanowiska menedżerskiego, ponieważ niektóre z metod służą wyłącznie do oceny wybranych składników kompetencji (np. testy wiedzy merytorycznej), a inne metody mają bardziej kompleksowy charakter i umożliwiają ocenę różnych składników kompetencji menedżerskich (np. ośrodek oceny lub ośrodek rozwoju, wartościowanie kompetencji).

Ze względu na złożoną strukturę wewnętrzną kompetencji autorka proponuje stosować agregatową ocenę kompetencji. Koncepcja ta oparta jest na podejściu całościowym, które zwiększa trafność diagnozy, ponieważ sprowadza się do statystycznej i dynamicznej oceny kompetencji kadry menedżerskiej. Celem statystycznej oceny kompetencji jest wycena punktowa profili kompetencyjnych dla poszczególnych stanowisk menedżerskich pozwalająca na określenie ich wzorcowego pozio$\mathrm{mu}$, a celem dynamicznej oceny kompetencji jest diagnoza rzeczywistej wartości kompetencji menedżerskich. W przypadku oceny statystycznej zastosowanie znajduje analityczno-punktowa metoda wartościowania kompetencji menedżerskich, a w przypadku oceny dynamicznej wykorzystuje się model 360 stopni oraz aktualną dokumentację organizacyjną i ekonomiczną, zawierającą potwierdzenie dokonań menedżera. Oparcie procesu oceny na zasadach podejścia całościowego pozwala 
precyzyjnie określić stopień kompetencyjności menedżera oraz wskazać lukę kompetencyjną i ustalić przyczyny jej powstania.

\section{Literatura}

Czubasiewicz H., 2005, Okresowe ocenianie pracowników. Konfiguracja i projektowanie systemu, Wyd. Uniwersytetu Gdańskiego, Gdańsk.

Czubasiewicz H., Nogalski B., 2010, Rozwój kompetencji menedżerskich. Praktyka pomorskich firm, Prace Naukowe Uniwersytetu Ekonomicznego we Wrocławiu, nr 115.

Jabłoński M., 2011, Koncepcje i modele kompetencji pracowniczych w zarządzaniu, CeDeWu.pl Wyd. Fachowe, Warszawa.

Kupczyk T., Stor M., 2017, Zarządzanie kompetencjami, Teoria, Badania i Praktyka Biznesowa, Wyd. Wyższa Szkoła Handlowa we Wrocławiu, Wrocław.

Kwiatkowski S.M., 2004, Problemy terminologiczne w procedurach standaryzacji kwalifikacji zawodowych, [w:] Kwalifikacje zawodowe na wspótczesnym rynku pracy, red. S.M. Kwiatkowski, Instytut Badań Edukacyjnych, Warszawa.

Miś A., 2007, Koncepcja rozwoju kariery zawodowej w organizacji, Wyd. Uniwersytetu Ekonomicznego w Krakowie, Kraków.

Nieżurawska J., 2010, Elastyczne systemy wynagrodzeń w przedsiębiorstwach w Polsce, TNOiK, Toruń.

Oleksyn T., 2018, Zarzadzanie kompetencjami, teoria i praktyka, Wolters Kluwer Business, Warszawa.

Pervin L.A., 1989, Persons, situations, interactions: The history of a controversy and a discussion of theoretical models, Academy of Management Review, vol. 14, nr 3.

Rakowska A., Sitko-Lutek A., 2000, Doskonalenie kompetencji menedzerskich, Wyd. Naukowe PWN, Warszawa.

Rozporządzenie Ministra Pracy i Polityki Społecznej z dnia 8 grudnia 2004 r. w sprawie klasyfikacji zawodów i specjalności dla potrzeb rynku pracy oraz zakresu jej stosowania, Dz.U. nr 265, poz. 2643 i 2644.

Tyrańska M., 2015, Koncepcja systemu oceny kompetencji kadry menedżerskiej w przedsiębiorstwie, Wyd. Uniwersytetu Ekonomicznego w Krakowie, Kraków.

Whiddett S., Hollyforde S., 2003, Model kompetencyjne w zarządzaniu zasobami ludzkimi, Oficyna Ekonomiczna, Kraków.

Wieczorek-Szymańska A., 2012, Metody pomiaru kompetencji pracowników organizacji, Studia i Prace Wydziału Nauk Ekonomicznych i Zarządzania, nr 30.

Witkowski S., 1995, Psychologiczna prognoza efektywności kierowania. Możliwości i ograniczenia, Wyd. Uniwersytetu Wrocławskiego, Wrocław.

Wyrzykowska B., 2016, Model kompetencyjny menedżerów w spółdzielniach mleczarskich, Marketing i Rynek, r. 23, nr 3, CD.

Zbiegeń-Maciąg L., 2006., Etyczne przedsięwzięcia w organizacji, [w:] Nowe tendencje $i$ wyzwania w zarządzaniu personelem, red. L. Zbiegeń-Maciąg, Oficyna a Wolters Kluwer Business, Kraków. 